\title{
Anatomia herbarza
}

Mariusz Kazańczuk

TEKSTY DRUGIE 2019, NR 2, S. 276-288

DOI: $10.18318 /$ td.2019.2.20 | ORCID: 0000-0002-4183-7291

Staropolscy koryfeusze heraldyki, choć bez wątpienia znali słowo „herbarz", nie umieszczali go w tytułach swoich prac. Uczynił to natomiast Marcin z Urzędowa, któremu sławę przyniósł Herbarz polski to jest o przyrodzeniu ziół i drzew rozmaitych (Kraków 1595). W XVI i jeszcze XVII wieku „herbarz” znaczyło tyle, co „książka zawierająca opisy roślin, zielnik, herbarius liber"'. Warto zatem pamiętać o tym, że staropolskie księgi herbowe nie były kiedyś herbarzami². Miano to na dobre przylgnęło do nich dopiero w XIX wieku, czego przykładem jest Korona polska Kaspra Niesieckiego, której drugie wydanie z lat 1839-1846, (przygotowane przez Jana Nepomucena Bobrowicza) nosi tytuł dokładnie taki sam jak rozprawa XVI-wiecznego botanika - Herbarz polski.

1 K. Nizio Herbarz w: Słownik polszczyzny XVI wieku, red. M.R. Mayenowa, F. Pepłowski, Ossolineum, Wrocław 1974, t. 8, s. 324.

2 Słowo "herbarz" pojawia się po raz pierwszy na karcie tytułowej książki Stanisława Duńczewskiego Herbarz wielu domów Korony Polskiej i W. Ks. Litewskiego, Drukarnia B. Jana Kantego, Kraków 1757, t. 1-2.

\section{Mariusz Kazańczuk}

- dr hab., starszy

dokumentalista

w Pracowni Literatury

Średniowiecza IBL

PAN. Jego zaintere-

sowania badawcze

koncentrują się wokół trzech tematów:

1) heraldyka szlachecka i jej rola w kulturze dawnej Polski;

2) staropolska proza narracyjna; 3) mediewalizm. Wydał m.in.: edycję nowel Michała Jurkowskiego Historyje świeże i niezwyczajne (2004), Barokowy romans na kanwie średniowiecznej fabuły (Oblicza mediewalizmu, 2013). Kontakt: mariusz.kazanczuk@ ibl.waw.pl 
Z tradycjiXIX-wiecznej wywodzi się współczesna kategoria genologiczna herbarza. Magdalena Piskała w konkluzji ciekawego artykułu stwierdza, że w odniesieniu do piśmiennictwa staropolskiego należy ją rozumieć szero$\mathrm{ko}^{3}$. Owszem, nawet bardzo, skoro w jej granicach mają się zmieścić dzieła dość zróżnicowane pod względem formy. Parafrazując słowa niemieckiego uczonego Karlheinza Stierlego, można powiedzieć, że dziełu nadaje kształt jego funkcja ${ }^{4}$. Książki nazywane obecnie herbarzami staropolskimi pełniły niegdyś rozmaite funkcje, z czego też wynikały różnice między nimi.

Manuskrypt heraldyczny autorstwa jezuity Jana Kołozwarskiego 5 mógł się na pierwszy rzut oka wydawać jedynie mało oryginalnym herbarzem, na którym niedobre piętno odcisnęła „praktyka bezkrytycznego przepisywania z prac już opublikowanych"6. Nie sposób wszak było podtrzymać tego zarzutu, kiedy jego autor okazał się profesorem retoryki, a sam herbarz kodeksem szkolnym, mającym być pomocą w nauczaniu tej sztuki .

Podobną funkcję przypisałem kiedyś monumentalnemu herbarzowi Szymona Okolskiego Orbis Polonus ${ }^{8}$, lecz pogląd ten został ostatnio zakwestionowany przez Jakuba Z. Lichańskiego' ${ }^{9}$. Książka będąca kompendium wiedzy, a zarazem zbiorem wzorów zastosowania w oracjach symboliki herbowej, zdaniem Barbary Milewskiej-Waźbińskiej mogła służyć „jako specyficzny podręcznik z zakresu retoryki"10. Jeżeli nie taka, to jaka była funkcja owego dzieła? Na to pytanie Lichański nie odpowiada.

3 M. Piskała Herbarz (staropolski) jako gatunek literacki, „Teksty Drugie” 2015 nr 1, s. 355.

4 K. Stierle Historia jako exemplum - exemplum jako historia. O pragmatyce i poetyce tekstów narracyjnych, przeł. M. Łukasiewicz, „Pamiętnik Literacki” 1978 z. 4, s. 337.

5 Rękopis Biblioteki Raczyńskich w Poznaniu z r. 1647 (nr 315, II. K.c. 43).

6 Z. Pentek XVII-wieczny herbarz rękopiśmienny ze zbiorów Biblioteki Raczyńskich w Poznaniu, "Gens" 1993, S. 121.

7 M. Kazańczuk Co może łączyć herbarz ze zbiorem nowel? O funkcji retorycznej kodeksów rękopiśmiennych Jana Kołozwarskiego i Michała Jurkowskiego, w: Retoryka Towarzystwa Jezusowego i jej konteksty, red. Ł. Cybulski, K. Koehler, Wydawnictwo UKSW, Warszawa 2014, s. 69-67.

8 M. Kazańczuk Staropolskie legendy herbowe, Ossolineum, Wrocław 1990, s. 34; tegoż Staropolskie herbarze. Herby - historia - religia, "Pamiętnik Literacki” 2002, z. 3, s. 41.

9 J.Z. Lichański Szymon Okolski - retoryka, historia, heraldyka , Rocznik Polskiego Towarzystwa Heraldycznego", nowej serii t. 13 (24), s. 100, 107. 
Nazwa „herbarz" przylgnęła także do dodatku heraldycznego, w który Mateusz Ignacy Kuligowski zaopatrzył swojego Demokryta śmiesznego (1699). Dodatek ten jest niczym innym, jak zbiorem wierszy omawiających najważniejsze herby polskie:

Wszystkich nie piszę herbów, które wyrażone

Są w kronikach autorów, tylko położone

Te są: które mogą być młodzi ekscytarzem

Do męstwa i cnót. Bom tu nie jest kronikarzem

Ani po stronach szukam herbów nie wpisanych

Do ksiąg, których jest dotąd wiele zaniedbanych."

W obrębie literatury heraldycznej doby staropolskiej jest to ważne świadectwo świadomości genologicznej. Wynika z niego, że herbarze uważano ówcześnie za dzieła kronikarskie ${ }^{12}$. Oczywiście tylko niektóre, nie wszystkie. Łatwo było skompilować książkę herbową na podstawie publikacji już istniejących. Z o wiele większym trudem wiązało się szukanie „po stronach” nieznanych herbów, dotąd nie odnotowanych, wertowanie dokumentów i kronik. Kto podejmował taką pracę, ciągnącą się czasem latami, ten niewątpliwie zasługiwał na miano kronikarza. „Wszystkich nie piszę herbów, które wyrażone / Są w kronikach autorów [...]"13. Ksiądz Kuligowski miał być może na myśli Joachima Bielskiego ${ }^{14}$, ale najpewniej Bartosza Paprockiego, autora pierwszych nowożytnych herbarzy polskich, których sława dotrwała do XVIII wieku, a nawet później.

Badacze nie zawsze byli skłonni uznawać pisma heraldyczne Paprockiego za twórczość historyczną. W syntezie Jerzego Ziomka czytamy:

Ale nas tu najbardziej interesują utwory takie jak: Panosza to jest Wysławienie panów i paniąt ziem ruskich i podolskich (Kraków 1575), Gniazdo cnoty (Kraków 1578), Herby rycerstwa polskiego (Kraków 1584). Są to prace heraldyczne, ale swoistej odmiany - wierszowane lub w części wierszowane

\footnotetext{
11 M.I. Kuligowski Demokryt śmieszny albo śmiech Demokryta chrześcijańskiego, Drukarnia Akademicka Societatis Jesu, Wilno 1699, s. 143. 
wykazy rodów szlacheckich. Przypominają poniekąd Rejowy Zwierzyniec, ale i znacznie różnią się od niego. Rej rozdawał ukłony i pochwały zaprzyjaźnionej szlachcie. Paprocki buduje legendy, szuka protoplastów, wywodzi i opowiada dzieje rodów zmyślone, a raczej sprytnie i pretensjonalnie wplecione w wędrowne motywy fabularne. Trudno Paprockiego nazwać historykiem $[\ldots]^{15}$

Trudno zgodzić się z tą opinią. Panosza, prezentujący herby szlacheckie w ramach zbioru wierszowanych wizerunków, pracą historyka jeszcze nie jest, ale Gniazdo cnoty już tak.

Po przekartkowaniu nieliczbowanej części wstępnej, zawierającej m.in. dedykację dla króla Stefana Batorego i przedmowę do czytelnika, natrafiamy na okazały drzeworyt, przedstawiający Lecha i Czecha, nad którym widnieje tekst par excellence kronikarski: „Masz tu naprzód jako się to zacne Królestwo Polskie zaczęło, kto rozszerzył na dłuż i na szerz granice jego, według dawnych historyków opisania. Roku po Narodzeniu na świat Syna Bożego 550"16. Wspomniana grafika otwiera galerię portretów monarszych (które wykorzystał już wcześniej wydawca Macieja Miechowity ${ }^{17}$ ), opatrzonych imionami kolejnych władców oraz datami.

Ponieważ dzieje bajeczne obejmują zaledwie kilkanaście stron, będzie na nich aż gęsto od ilustracji, prezentujących m.in.: Kraka, Wandę i pożeranego przez myszy Popiela. Ten sam obrazek z przedstawieniem dwunastu wojewodów, dzierżących w dłoniach miecze i włócznie, powtórzony dwukrotnie, „obsłuży” dwa bezkrólewia, które spadły na Polskę „Po zejściu potomstwa Lechowego”18 oraz „Po śmierci Wandy”"

Nad konterfektem Mieszka I przeczytamy: „Mieszko, syn Ziemomisławów, który się był ślepo urodził, na Monarchiją Polską obran roku 962"20. Postać władcy w koronie i z berłem, wyrastająca jakby z krzewu winnej latorośli, ma po prawej swojej stronie portrecik żony Dąbrówki (podpisany: „dziewka

15 J. Ziomek Renesans, PWN, Warszawa 1980, s. 391-392.

16 B. Paprocki Gniazdo cnoty, Drukarnia Andrzeja Piotrkowczyka, Kraków 1578, s. 1.

17 J. Krauze-Karpińska XVI-wieczne drukowane realizacje tekstów heraldycznych, "Rocznik Polskiego Towarzystwa Heraldycznego" nowa seria t. 13 (24), s. 85.

19 Tamże, s. 5.

20 Tamże, s. 13. 
książęcia czeskiego”21), zaś po lewej - syna Bolesława („którego potym Ruś nazwali Chrabry"22). Panowanie pierwszego chrześcijanina na tronie polskim zostało przedstawione w wierszu liczącym tylko 12 wersów ${ }^{23}$. A pod portretem Stefana Batorego, koronowanego na króla Polski niedługo przed wydaniem dzieła, znalazł się wiersz nawet o cztery wersy krótszy ${ }^{24}$.

Gdybyśmy mieli wskazać główny temat dzieła, musielibyśmy powiedzieć: walki rycerzy (ukazanych tu jako założyciele poszczególnych rodów) pod wodzą władców z wrogami Polski. Tematycznie Gniazdo cnoty zbliża się do kroniki Galla (który - jak zauważa Paweł Żmudzki - „deklarował wprost, że dzieje konfliktów zbrojnych są zasadniczym tematem jego utworu"25), z drugiej zaś strony, poddane rygorowi dat, łączy się z historiografią rocznikarską typu Długosza. Przekazywaniu treści historycznych służą tutaj w równym stopniu słowa i obrazy.

Paprocki pieczołowicie odtwarza genealogię domu królewskiego (a właściwie dwóch domów: Piastów i Jagiellonów), która na kartach Gniazda cnoty prezentuje się dosyć przejrzyście, bo to przecież książka ilustrowana. Wizerunki władców (powtarzają się co jakiś czas, bo klocków drzeworytniczych było mniej niż monarchów) otaczają mniejsze portrety żon i dzieci. Każdy opatrzony jest podpisem. Od razu można się zorientować, kto kogo rodził i kto po kim dziedziczył tron. Przypomina to drzewo genealogiczne, tyle że tutaj jest ono jakby pocięte na kawałki. Wystarczy je wszakże złożyć w wyobraźni, by uznać jego wspaniałość. Ponieważ genealogia była niejako profesją $\mathrm{Pa}-$ prockiego, w jego księdze, mówiąc obrazowo, wokół drzewa królewskiego wyrastają mniejsze drzewa rodów szlacheckich.

Dla dawnych czytelników pierwszy nowożytny herbarz polski był niewątpliwie dziełem kronikarskim. Natomiast nazwanie go dzisiaj kroniką może budzić wątpliwości, zbyt bowiem odbiega od współczesnych, popularnych wyobrażeń na temat herbarzy ${ }^{26}$. Jednak ten, kto przeczyta lub choćby przewertuje herbarz Paprockiego od początku do końca: od króla Lecha

21

22

23

24

25

26

Tamże, s. 13 .

Tamże.

Tamże.

Tamże, s. 1242.

P. Żmudzki Władca i wojownicy. Narracje o wodzach, drużynie i wojnach w najdawniejszej historiografii Polski i Rusi, FUNNA, Wrocław 2009, s. 6.

6 Zob. M. Kazańczuk Staropolskie herbarze, s. 39-41. 
do Stefana Batorego, dostrzeże w nim strukturę kroniki, gdzie autor, zachowując ściśle układ chronologiczny, odmierza czas okresami panowania kolejnych władców oraz datami rocznymi, które dołącza nie tylko do ich imion i portretów. Także do herbów szlacheckich, dzięki czemu nie są już one ahistoryczne.

Strukturę Gniazda cnoty określa jego funkcja, którą jest nie tylko przedstawienie pocztu herbów w połączeniu z genealogiami rodów, ale także opowiedzenie historii Polski. Dzieje ojczyste relacjonuje Paprocki jednak w zupełnie inny sposób niż poprzednicy. Jego dzieło tym się bowiem różni od wcześniejszych kronik, że pokazuje wydarzenia z perspektywy bardziej rodów szlacheckich niż państwa i dynastiii ${ }^{27}$.

Kronikarski charakter Gniazda cnoty zostanie uwypuklony, jeśli porównamy je z kroniką Bielskiego. Nie Marcina, ale jego syna Joachima, którego dzieło stanowi znacznie rozszerzoną wersję księgi 8 Kroniki wszytkiego świata (1551, 1564). Elementem rozszerzającym są w nim m.in. umieszczone na marginesach rysunki herbów szlacheckich oraz ich historie (legendy herbowe) - przez autora Kroniki polskiej (1597) wzięte właśnie od Paprockiego wplecione, podobnie jak w Gnieździe cnoty, w chronologię dziejów ogólnych, co u obydwu kronikarzy można uznać za „wyraz ostatecznego splecenia się czasu genealogicznego z czasem państwowym" oraz za świadectwo identyfikacji szlachty z państwem ${ }^{28}$. Różnica między Paprockim a Bielskim polega wszak na tym, że u pierwszego historie herbów (tudzież genealogie rodów) górują nad historią państwa, zaś u drugiego jest odwrotnie.

Warto przy okazji zauważyć, że samo połączenie materii heraldycznej i historiograficznej nie było wynalazkiem autora Gniazda cnoty. Zainteresowanie herbami przejawiali już kronikarze średniowiecznii' ${ }^{29}$, czego przykładem na gruncie polskim są Roczniki Długosza ${ }^{30}$.

27 Wydanie Gniazda cnoty przypadło na pierwsze lata monarchii elekcyjnej będących, jak wiadomo, okresem wzrostu politycznego znaczenia szlachty. Paprocki dokonał niewątpliwie czegoś doniosłego, znajdując dla jej antenatów miejsce w historii, co w oczywisty sposób legitymizowało posiadane przez nią prawa i przywileje.

T. Jakimowicz Temat historyczny w sztuce ostatnich Jagiellonów, PWN, Warszawa-Poznań 1985, s. 90 .

O. Neubecker Le grand livre de l'héraldique: I'histoire, l'art et la science du blason, adaptation française R. Harmignies, Elsevier Séquoia, Paris-Bruxelles 1977, s. 28. 
W Gnieździe cnoty dominuje mowa wiązana. Jednak zawarte w dziele teksty wierszowane: stemmata, wizerunki, legendy herbowe, na niektórych stronnicach sąsiadują z ustępami prozatorskimi. Takie są m.in. relacje biograficzne o bohaterskich czynach kilku osobistości z XVI wieku³1. Książka, mająca charakter popularny, pozbawiona jest przypisów źródłowych. Spotykamy się w niej jedynie z ogólnym stwierdzeniem, powtarzanym wielokrotnie, że coś przedstawione zostało „według historyków dawnych opisania”. Nie ulega wszak wątpliwości, że za tą formułką kryła się znajomość dzieł kronikarskich. Skąd bowiem, jeśli nie z kronik, wziąłby autor te wszystkie daty, którymi opatrzył swój tekst.

Warsztat historyczny Paprockiego ujawnia dopiero jego drugi herbarz Herby rycerstwa polskiego (1584) - bardziej uczony, obszerniejszy, napisany prozą (przetykaną wierszami łacińskimi i polskimi). Pracując nad nim, wykorzystał on m.in. teksty: Galla Anonima ${ }^{32}$, Wincentego Kadłubka, Kroniki wielkopolskiej, Jana Długosza, Macieja Miechowity i Marcina Kromera ${ }^{33}$.

Strukturę Herbów rycerstwa polskiego przedstawił sam autor w przedmowie do czytelnika ${ }^{34}$. W pierwszej części dzieła, zatytułowanej: O Orle klejnocie, który tylko samym królom polskim należy, znalazły się opisy panowania władców polskich od Lecha do Ludwika Węgierskiego. Warto zauważyć zawarte w niej cytaty z kroniki Galla Anonima ${ }^{35}$. Dwie następne części herbarza prezentują, w układzie jakoby chronologicznym, herby szlachty polskiej, genealogie poszczególnych rodów, fragmenty biografii ich znaczniejszych przedstawicieli. Część czwarta, rozpoczynająca się od opisu Pogoni - herbu Wielkiego Księstwa Litewskiego, przedstawia przodków dynastii Jagiellonów oraz dzieje monarchii po zjednoczeniu Polski i Litwy: od Władysława Jagiełły do Stefana Batorego. Dzieło wieńczą „księgi piąte”, poświęcone herbom województw i ziem Rzeczypospolitej.

B. Paprocki Gniazdo cnoty, s. 1031-1033, 1162-1165, 1183-1186, 1235-1238.

M. Kazańczuk Czy Bartosz Paprocki znał Kronikę Galla?, w: Oblicza mediewalizmu II. Od recepcji antyku do recepcji średniowiecza (materiały V Kongresu Mediewistów Polskich, t. 7), red. A. Dąbrówka, M. Michalski, G. Trościński z udziałem S. Jędrzejewskiej, Wydawnictwo URz, Rzeszów 2018, s. 127-139.

W. Dworzaczek Paprocki Bartłomiej w: Polski Słownik Biograficzny, Ossolineum, Wrocław 1980, t. 25 , s. 179 .

4 B. Paprocki Herby rycerstwa polskiego, wyd. K.J. Turowski, Wydawnictwo Biblioteki Polskiej, Kraków 1858, s. 10-11.

Tamże, s. 19, 25-26. 
Zważywszy strukturę drugiego herbarza Paprockiego, przedstawioną powyżej, trudno byłoby go jednak w całości traktować jako kronikę. Mamy tu raczej do czynienia z kompendium wiadomości heraldyczno-genealogiczno-biograficznych, co ciekawe, w układzie chronologicznym, wpisanych w kronikarską ramę dziejów Rzeczypospolitej (części pierwsza i czwarta).

W Herbach rycerstwa polskiego, podobnie jak w Gnieździe cnoty, doszło do połączenia dwóch wymiarów historii: państwa z jednej i „narodu szlacheckiego" z drugiej strony. Z tego względu należy w nich widzieć dzieła wyjątkowe, jakich wcześniej nie było.

Ziomek, jak już wspomniano, nie uznał Paprockiego za historyka. Lecz jest to opinia dawniejsza, bo dzisiaj nazywa się go nawet „historykiem krytycznym". Czyni to Marek Cetwiński w artykule, którego tytuł zawiera intrygujące sformułowanie: „Paprocki jako historyk krytyczny”. Autor publikacji pisze:

Historia Polski - bo tym w istocie są Herby [podkreśl. - M.K.] - nie miała być już od tej pory dziełem monarchów, lecz całej aktywnej klasy politycznej. W dobie pierwszych elekcji pogląd taki wydaje się naturalny - wszak suwerenem stawał się szlachecki ogół właśnie, a nie dziedziczny monarcha. Wewnątrz tego stanu wprawdzie idea równości jeszcze nie zatriumfowała całkowicie. Wciąż pewne rody uznawano za lepsze, bo starsze. Chronologiczny układ Herbów Bartosza Paprockiego wymownie ilustruje tę hierarchię. Dalsze postępy szlacheckiej demokracji, doktryna równości wewnątrz stanu doprowadzają w późniejszych polskich herbarzach do zastąpienia układu chronologicznego układem alfabetycznym. Staropolskie herbarze okazują się - jak widać - czułym wskaźnikiem postępów szlacheckiej demokracji. Ta ostatnia zaś rodzi przekonanie, iż historia jest dziełem zbiorowości, a nie jednostek, choćby koronowanych. To zmiana istotna w sposobie pojmowania dziejów i to właśnie Bartosz Paprocki, rozwijając idee zawarte w pracach kilku poprzedników, dał jej wyraz w swych dziełach. A to pozwala uznać go już za jednego z pionierów pojmowania historii w sposób zbliżony do obecnego. ${ }^{36}$

Obowiązki kronikarza-heraldyka, którym z dobrym skutkiem stawił czoła autor Herbów rycerstwa polskiego, a od których, jak pamiętamy, uchylił się Kuligowski, odważnie wziął na siebie Kasper Niesiecki. Efektem tego były cztery

36 M. Cetwiński Nie tylko "Walgierz i Helgunda” czyli Paprocki jako historyk krytyczny, "Rocznik Polskiego Towarzystwa Heraldycznego", nowa seria t. 13 (24), s. 12-13. 
wielkie tomy, cieszące się opinią najwybitniejszego herbarza dawnej Polski. Już na pierwszy rzut oka widać, jak bardzo różni się on od dzieł Paprockiego, przede wszystkim układem, podyktowanym nie chronologią, ale porządkiem alfabetycznym (zgodnie z którym uszeregowano zarówno herby, jak i rody), co nadaje mu kształt encyklopedycznego kompendium heraldyczno-genealogicznego. Gdyby twórca Korony polskiej, jak jego poprzednik, przedstawił je hierarchicznie, wedle starszeństwa, to zapewne naraziłby się na większe jeszcze przykrości niż te, które spotkały go ze strony szlachty, tak drażliwej na punkcie własnego pochodzenia ${ }^{37}$.

Cetwiński ma niewątpliwie rację, twierdząc, że idea równości wpłynęła na kształt późniejszych herbarzy staropolskich, choć przecież w nich także nie można było uniknąć wynoszenia jednych rodów ponad drugie. To oczywiste, że Niesiecki o wielkich „domach” rozpisywał się szeroko, a o małych pisał niewiele albo zgoła nic, skoro niekiedy nawet nie miał pojęcia o ich istnieniu, a opieszali czytelnicy, na co się uskarżał, nie dostarczali mu niezbędnych informacji ${ }^{38}$. W każdym razie, mimo że wzbudził tyle niezadowolenia wśród współczesnych, u potomnych zasłużył na szacunek, gdyż zadania,jakie przed sobą postawił, wypełnił bardzo rzetelnie i rzecz doprowadził do końca.

Zakres kwerendy źródłowej pracowitego jezuity z godną podziwu skrupulatnością odtworzyła Iwona M. Dacka ${ }^{39}$. Wykorzystywał on w swojej pracy m.in. dzieła historiograficzne, biograficzne i hagiograficzne, co nie pozostało bez wpływu na strukturę gatunkową Korony polskiej. Dzieło przedstawiające dzieje i genealogie rodów szlacheckich oraz początki herbów, jakimi się one pieczętowały - to oczywiście nie jedyne oblicze herbarza Niesieckiego, który zawiera ponadto obszerne biografie postaci zasłużonych dla Ojczyzny: dowódców wojskowych, pisarzy, dostojników świeckich i duchownych. Jeszcze więcej miejsca zajmują w nim żywoty polskich świętych, błogosławionych i kandydatów na ołtarze, świątobliwych mężów (zwłaszcza z Towarzystwa Jezusowego) i niewiast ${ }^{40}$.

37 W. Dworzaczek Niesiecki Kasper, w: Polski Słownik Biograficzny, Ossolineum, Wrocław 1978, t. 23, s. 49 .

38 K. Niesiecki Korona polska, Drukarnia Collegium Lwowskiego Societatis Jesu, Lwów 1728-1743, t. 4 , s. $817-818$. I.M. Dacka "Korona polska" Kaspra Niesieckiego. Pomnik staropolskiego piśmiennictwa staropolskiego, DiG, Warszawa 2004, s. 61-16o.

40 M. Kazańczuk "Korona polska” Kaspra Niesieckiego jako dzieło religijne, "Pamiętnik Literacki” 1995 Z. 2, S. 139-151. 
Ciało swoje wykwintnie katowała, już paskami, już manelkami drutowymi, już włosiennicą, już postami. Nadto ręce do góry podniesione bez podpory długo trzymała, pokrzywami się siekła, stoczki o ciało swoje gasiła $[\ldots]^{41}$

$\mathrm{Na}$ licznych stronnicach rozsiane są historie budujące, powiązane z portretowanymi osobami. Niektóre z tych narracji dają się rozpoznać jako przykłady z kazań Franciszka Kowalickiego, konfratra autora, żyjącego w tej samej, co on, epoce ${ }^{42}$.

Pod koniec XVIII wieku Ewaryst Andrzej Kuropatnicki zarzucał Niesieckiemu:

Uchybił [on] zamiaru swego, bo przedsięwziął pisać o herbach, domach, ich początkach, ozdobach, w samej zaś rzeczy starał się okazać, jako zgromadzenie zakonu jego jest szlachetne, życie zakonników jego jak święte, jak cudowne, na koniec fundatorów i dobrodziejów zakonu swego wiekopomnej podał pamięci i ich czyny $[\ldots]^{43}$

Trudno uznać tę ocenę za sprawiedliwą, skoro „o herbach, domach, ich początkach, ozdobach" napisał jezuita więcej niż jakikolwiek z jego poprzedników. Pozostaje jednak faktem, że nader często wychodził poza materię heraldyczno-genealogiczną. Jego dzieło jawi się nam jako nie tylko kompendium herbowe, przetykane biografiami wybitnych Polaków, lecz także zbiór żywotów świętych i kolekcja egzemplów. Dlaczego Korona polska przybrała właśnie taki kształt? Konstytucja tekstu - twierdzi Stierle - „uzależniona jest od użytku, jaki się zeń czyni" "44. Ważne jest to, kto pisze i dla kogo. Obfitość treści religijnych w herbarzu Niesieckiego tłumaczy oczywiście profesja zakonna autora. Ale nie tylko. Również adresat zbiorowy książki. A jest nim utwierdzona w katolicyzmie szlachta epoki saskiej.

Warto zwrócić uwagę na osoby, którym dedykowano kolejne trzy tomy dzieła (czwarty nikomu nie został przypisany). Są nimi same kobiety: Matka

41 K. Niesiecki Herbarz polski, wyd. J. N. Bobrowicz, Breitkopf i Haertel, Lipsk 1839-1846, t. 6, s. 159.

Historie dziwne i straszliwe. Jezuickie opowieści z czasów saskich, oprac. M. Kazańczuk, Verba, Chotomów 1991, s. 81, 83, 91-93, 95-97, 107. nie Polskiej i Wielkim Księśtwie Litewskim, Drukarnia Michała Grölla, Warszawa 1789, s. VI. 
Boska, Marianna z Potockich Tarłowa i Franciszka Urszula z Wiśniowieckich Radziwiłłowa. Pobożna adresatka tomu drugiego, żona Adama Tarły, była córką równie pobożnej matki, tej właśnie, co „ciało swoje wykwintnie katowała". Świątobliwej Krystynie z Lubomirskich Potockiej, dobrodziejce jezuitów krasnostawskich, poświęcono w herbarzu znacznie więcej miejsca niż jej bratu, sławnemu Stanisławowi Herakliuszowi Lubomirskiemu ${ }^{45}$.

Kasper Niesiecki zaadresował swoje dzieło do określonego kręgu odbiorców. Były w nim także kobiety. Czy to nie ze względu na nie postanowił napisać swoje dzieło po polsku?

Herbarze Paprockiego i Niesieckiego, poddane rozbiorowi, ujawniają swoją heterogeniczną budowę, wskazującą na niezwykłą różnorodność gatunkową. Dzieła te uderzają nas odmiennościami, lecz łączy je to, że wszystkie trzy - w rozmaity sposób - odwołują się do dziejów państwa, nawet Korona polska, o czym świadczy wstępna część dzieła, przedstawiająca herby: Królestwa Polskiego, Wielkiego Księstwa Litewskiego, kapituł, a także województw i ziem. Graficzne przedstawienia tych herbów są opatrzone obszernym komentarzem historycznym, zawierającym także spisy władców Polski i Litwy, hierarchów kościelnych i urzędników państwowych ${ }^{46}$. Pomysł połączenia tego wszystkiego z dziejami rodów szlacheckich przywodzi na myśl historiozoficzną ideę Paprockiego - żywą, jak się okazuje, nie tylko w epoce powstania monarchii elekcyjnej, lecz także u schyłku Rzeczypospolitej.

Wstęp do Korony polskiej, będący obszernym opisem kraju i państwa jako całości - od tego właśnie zaczynają się dzieła dawnych kronikarzy - uzasadnia stwierdzenie: epistemologiczną ramą herbarza Niesieckiego jest kronika. Elementami opisu u jezuity, odmiennie niż w horografii Jana Długosza, umieszczonej na początku sławnych Roczników ${ }^{47}$, nie są kategorie topograficzne, lecz heraldyczne. Składowe części królestwa reprezentują tutaj herby województw i ziem. Podobnie jest także we wstępnej części kroniki Joachima Bielskiego, gdzie opis Polski zaczyna się od geografii, a kończy na heraldyce:

Krakowskie województwo na chorągwi używa Orła białego w złotej koronie, w czerwonym polu, a przez skrzydła ma złotą linią. W tymże województwie jest ziemia sądecka, która też ma osobną swą chorągiew, na

K. Niesiecki Herbarz polski, t. 6, s. 162-163.

Tamże, t. 1, s. 1-386; I.M. Dacka „Korona polska” Kaspra Niesieckiego, s. 59-60.

47 J. Długosz Annales seu cronicae incliti Regni Poloniae, lib. I-II, Warszawa 1965, s. 65-114. Zob. też

D. Platt Staropolskie chorografie, Wydawnictwo UŚ, Katowice 1995, s. 99-123. 
której na prawej stronie są trzy stryfy czerwone, a trzy żółte, a na drugiej dziewięć gwiazd w czerwonym polu. ${ }^{48}$

Niemal zwierciadlanym odbiciem tego fragmentu jest tekst Niesieckiego:

Herb jego [województwa krakowskiego - przyp. M.K.] Orzeł biały w złotej koronie, w polu czerwonem, przez skrzydła ma złotą linią. [...] W temże województwie trzy się ziemie rachują. Pierwsza sądecka, ta na prawej stronie choragwi nosi za herb trzy strefy czerwone i trzy żółte, tak że po każdej czerwonej żółta alternatą następuje, a na drugiej stronie dziewięć gwiazd w czerwonym polu, we trzy rzędy rozłożonych, w każdym zaś rzędzie po trzy gwiazdy jedna pod drugą. ${ }^{49}$

Oczywiście nie wszystkie herbarze staropolskie przyoblekały się w postać dzieł tak silnie nasyconych treściami historycznymi. Kuligowski, pozbawiony ambicji historiografa (Bom tu nie jest kronikarzem), napisał dziełko o zgoła odmiennym charakterze. Nawet wierszowane Gniazdo cnoty, w swej głębszej warstwie, niewiele będzie miało z nim wspólnego. Trudno też znaleźć większe podobieństwa między Kuligowskim a Kołozwarskim. A jednak i kronika herbowa, i kompendium heraldyczno-genealogiczne, i kolekcja wierszy na herby, i heraldyczna retoryka, jak uważa Piskała, m u s z ą się zmieścić w granicach genologicznej kategorii herbarza ${ }^{50}$. Skoro tak, to powinniśmy zadać sobie pytanie, jaki wspólny mianownik mają te formy. Poszukując go, znajdziemy słowo: „zbiór”. Rzeczywiście, wszystkie, wymienione w artykule, herbarze są zbiorami. Natomiast żadna pojedyncza prezentacja herbu, nawet w połączeniu z wywodem genealogicznym, jak w przypadku drukowanego kazania pogrzebowego, za herbarz uznana być nie może.

„[...] księga zawierająca opisy lub ilustracje herbów, komentarze dotyczące ich pochodzenia oraz informacje o rodzinach, które się nimi posługują"51 - tak brzmi współczesna definicja herbarza. Współczesna, ponieważ w wiekach, z których pochodzą staropolskie z bi o ry heraldyczne, jej nie

48 J. Bielski Kronika polska, Drukarnia Jakuba Siebeneychera, Kraków 1597, s. 4. Por. też A. Gwagnin Sarmatiae Europeae descriptio, Drukarnia Bernarda Albina, Spira 1581, k. 33r-34r.

K. Niesiecki Herbarz polski, t. 1, s. 124 . 
wypracowano, a ponadto „nie zaadaptowano w pełni wzorów zachodnioeuropejskich, ani też nie dopracowano się własnego modelu, za którym podążaliby kolejni heraldycy"52. Heraldyka i genealogia zajęła miejsce na tak wielu obszarach piśmiennictwa staropolskiego, że prace z tego zakresu były pisane różnymi językami: kronikarskim, retorycznym, poetyckim. Stąd biorą się kłopoty dzisiejszych badaczy. Problem stanowi zakreślenie granic gatunku, a i sam termin „herbarz" bywa czasem niewygodny, choć - rzecz jasna - nie sposób z niego zrezygnować.

\section{Abstract}

\section{Mariusz Kazańczuk}

THE INSTITUTE OF LITERARY RESEARCH OF THE POLISH ACADEMY OF SCIENCES (WARSAW)

The Anatomy of the Peerage

Scholars of heraldry in pre-modern Poland were no doubt familiar with the word "herbarz," which today signifies "peerage" (a book containing a list of peers and peeresses, with their genealogy and history), but until the nineteenth century was synonymous with "herbarium" (a collection of preserved plant specimens). In the context of old-Polish writing, the genre of the herbarz-peerage ought to be understood broadly, as it encompassed works that were quite different from one another. Kazańczuk discusses their differences by drawing on Karlheinz Stierle's notion that every work derives its form from its function. The questions who writes and for whom are crucial. Reflecting on the genre of the oldPolish peerage, the paper emphasizes this genre's relationship to historiography.

\section{Keywords}

heraldry, peerage, nobility, historiography, pre-modern Poland, genre studies, old-Polish literature 